WARSZTATY Z GEOGRAFII TURYZMU

ISBN 978-83-7969-262-0 $\quad$ s. 65-84

http://dx.doi.org/10.18778/7969-262-0.05

Alina ZAJADACZ

Uniwersytet im. A. Mickiewicza w Poznaniu

\title{
"CZAS PRZESZŁY DOKONANY" BADAŃ Z ZAKRESU TURYSTYKI, KRAJOZNAWSTWA I REKREACJI W POZNAŃSKIM OŚRODKU GEOGRAFICZNYM
}

Jeżeli bowiem przez geografię rozumieć będziemy w ogólnym znaczeniu wiedzę o Ziemi, a - w bardziej szczegółowym zastosowaniu - znajomość krajów, a w ostatecznym ujęciu syntezę stosunku człowieka

do Ziemi - to kto bez tej nauki może się obejść?

S. PAWŁOWSKI 1939.

\section{Wprowadzenie}

Jubileuszowe, XXX Warsztaty z Geografii Turyzmu, organizowane na Uniwersytecie Łódzkim, skłaniają do refleksji nad historią badań geograficznych dotyczących turystyki (jak i pokrewnych jej zagadnień - rekreacji czy krajoznawstwa). W historii tej szczególną rolę odegrały badania prekursorskie podejmowane przez osoby, które potrafiły łączyć twórczą pasję z konsekwentnym rozwojem problematyki badawczej, przez co w widoczny sposób wywarły wpływ na wybór "ścieżki naukowej” swoich uczniów, przyczyniając się do ukształtowania nurtów badawczych obecnych w geografii turyzmu.

Celem autorki pracy jest przypomnienie prekursorskich badań z zakresu turystyki, krajoznawstwa oraz rekreacji prowadzonych $\mathrm{w}$ poznańskim ośrodku geograficznym od momentu jego powstania, tj. od powołania w roku 1919 Instytutu Geograficznego na Uniwersytecie (zwanym wówczas 
Wszechnicą Piastowską, a od 1955 r. noszącym imię Adama Mickiewicza w Poznaniu), do 2000 r. Cezura 2000 r. związana jest z wyodrębnieniem w strukturze Wydziału Nauk Geograficznych i Geologicznych (WNGiG) Zakładu Centrum Turystyki i Rekreacji (ZCTiR) jako jednostki statutowo zorientowanej na prowadzenie badań i studiów z zakresu turystyki i rekreacji. Na przełomie XX i XXI w. "zamknięto" więc pewien etap badań, na którym problemy związane z krajoznawstwem, turystyką czy rekreacją były poruszane jako jedne $\mathrm{z}$ wielu $\mathrm{w}$ ramach geografii fizycznej i społeczno-ekonomicznej, rozpoczęto natomiast nowy etap, na którym zagadnienia te stały się głównym przedmiotem badań w działalności ZCTiR.

Analizowane lata 1919-2000 to czas miniony, w którym miały miejsce działania spełnione $\mathrm{w}$ przeszłości, zarówno związane $\mathrm{z}$ teraźniejszością, jak też nie wykazujące obecnie takiego związku - można go zatem uznać za „czas przeszły dokonany”. Porządkując dorobek geografów rozwijany w okresie ponad 80 lat (przerwanym działaniami II wojny światowej) korzystano ze zbiorów biblioteki i archiwum WNGiG. Dorobek ten wykazuje, że do prekursorskich w tym zakresie należą prace: prof. prof. Stanisława Pawłowskiego, Tadeusza Bartkowskiego, Danieli Sołowiej, Andrzeja Marsza, oraz Eugeniusza Bidermana. Prace te zainicjowały i rozwinęły kilka podstawowych nurtów w geografii turyzmu: krajoznawczy, fizycznogeograficzny, społeczno-ekonomiczny oraz badań kompleksowych.

\section{Nurt krajoznawczy}

Nierozerwalny związek między badaniami geograficznymi, turystyką i krajoznawstwem cechował działalność prof. Stanisława Pawłowskiego - geografa, który przybył do Poznania ze Lwowa w 1919 r., by w tym samym roku zaangażować się w tworzenie Instytutu Geograficznego na erygowanym uniwersytecie (fot. 1). Znamienne zarówno w działalności naukowej, jak i popularyzatorskiej Profesora było podkreślanie znaczenia wiedzy zdobywanej podczas wyjazdów turystycznych i wypraw krajoznawczych w rozwoju geografii. W roku 1928 z jego inicjatywy powstało w Poznaniu Towarzystwo Geograficzne. W roku 1932 S. Pawłowski został rektorem Uniwersytetu Poznańskiego, w 1938 r. wiceprezydentem Międzynarodowej Unii Geograficznej. Liczne prace na rzecz propagowania krajoznawstwa w Poznaniu i Wielkopolsce spowodowały, że w 1920 r., gdy Towarzystwo Krajoznaw- 


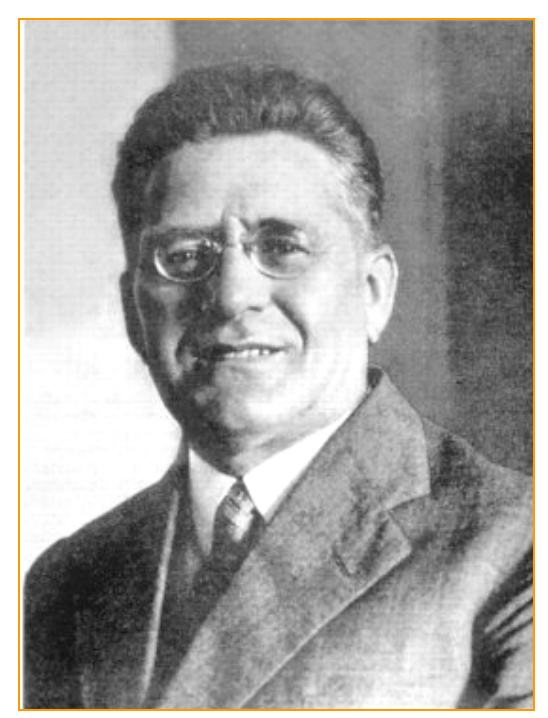

Fot. 1. Profesor Stanisław Pawłowski (1882-1940)

Źródło: Archiwum WNGiG UAM w Poznaniu

cze w Poznaniu przemianowano na oddział Polskiego Towarzystwa Krajoznawczego (PTK), Profesor został jego pierwszym prezesem. Przez wiele lat współpracował z czasopismem „Ziemia” (fot. 2, fot. 3).

Profesor S. Pawłowski był geografem wszechstronnym, co uwidoczniło się również w jego publikacjach w "Ziemi”. Pisał tu o metodach badań na powierzchni Ziemi, o polskim wybrzeżu, o Polesiu jako krainie geograficznej, ale też na temat głównych kierunków rozwoju sieci kolejowych w Polsce, stosunku krajoznawstwa polskiego, a nawet na modny pod koniec lat trzydziestych temat polskich zamierzeń kolonialnych [...]. Kontakt prof. Pawlowskiego z „Ziemią" trwał więc z przerwami 27 lat, czyli najdłużej w gronie piszących w tym czasie geografów (SZUKALSKI 1985).

Pod kierunkiem S. Pawłowskiego opracowano Atlas nazw geograficznych... (1935), wydany w polskiej, francuskiej i angielskiej wersji językowej (fot. 4.), który stanowił i nadal jest fundamentalnym dziełem dla opracowań krajoznawczych.

W okresie poprzedzającym II wojnę światową S. Pawłowski podkreślał stosowany charakter wiedzy geograficznej w różnych skalach gospodarowania $\mathrm{w}$ przestrzeni. 
Istotnie geografia, wyrażająca się w znajomości świata, w pewnym zespole wiadomości o własnym kraju i o krajach sąsiednich i dalszych - geografia, wnikająca w istotę stosunku tzw. warunków i czynników geograficznych do ludzkości - nie może nie zwracać uwagi i woli ludzkiej w kierunku dla tej ludzkości najkorzystniejszym. W tym sensie jest geografia nauką pożyteczną, a więc praktyczną, a nie teoretyczną tylko (PAWŁOWSKI 1939).

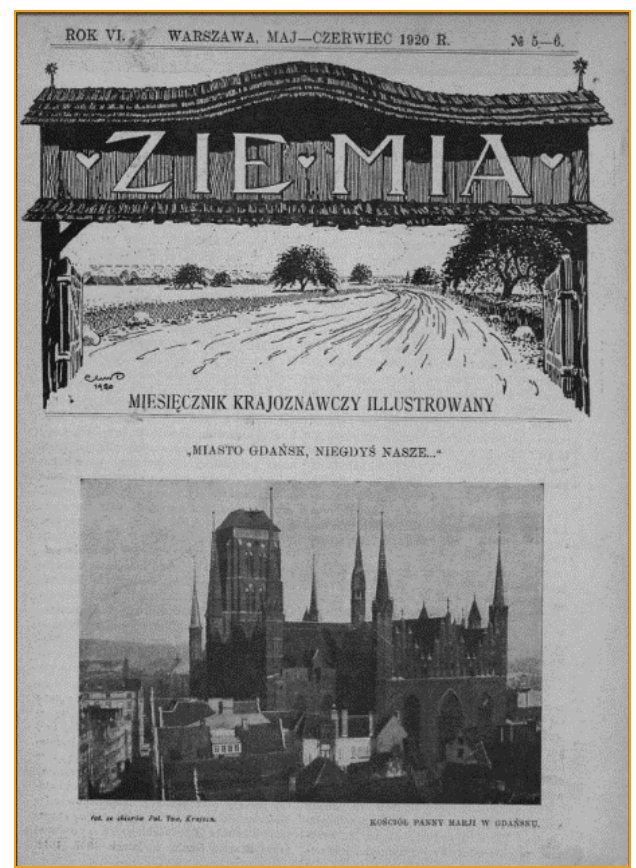

Fot. 2. Strona tytułowa czasopisma "Ziemia"(1920)

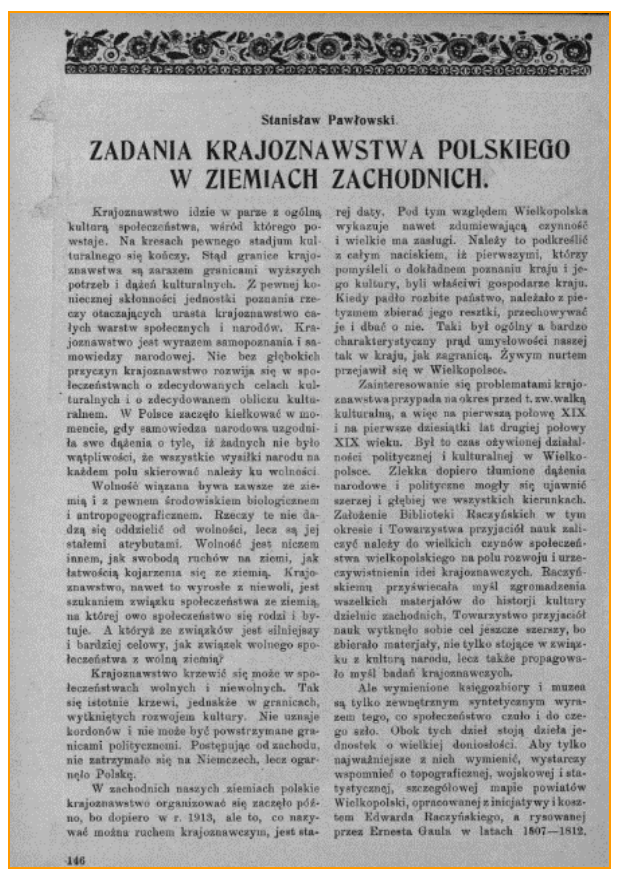

Fot. 3. Strona tytułowa publikacji S. Pawłowskiego w czasopiśmie „Ziemia"(1920)

Dostrzegał jednak problemy organizacyjne i badawcze związane z kondycją badań geograficznych.

Geografia polska dzieliła dotychczas losy innych nauk oraz innych dziedzin naszego życia umysłowego, tj. opierała się na jednostkach, idących przeważnie $\mathrm{w}$ odosobnieniu $\mathrm{i} \mathrm{w}$ różnych kierunkach. Nie było $\mathrm{w}$ niemłodej już u nas w Polsce nauce - a za taką musimy uważać geografię, ani ogólnych dążeń, ani wytycznych kierunków. Rozwój owej gałęzi wiedzy zależał od zdolności, woli, środków nielicznych jednostek, czasem nawet 
od przypadku. Nie stała za nim rzesza pracowników, lecz zaledwie garstka ludzi, często z sąsiednich nauk (PAWŁOWSKI 1919).

Próbą integracji środowiska geografów oraz organizacji ich pracy naukowej było powołanie Polskiego Towarzystwa Geograficznego, jak również rozwój PTK (PAWŁOWSKI 2006).

Zasługi Polskiego Towarzystwa Krajoznawczego są w Polsce powszechnie znane. Cele jednak sięgają głębiej do różnych warstw społeczeństwa niż cele Towarzystwa Geograficznego. Towarzystwo Krajoznawcze ma budzić ogólne zainteresowanie Ziemią ojczystą, jako też uwagi godnymi zjawiskami i przedmiotami (PAWŁOWSKI 1919).

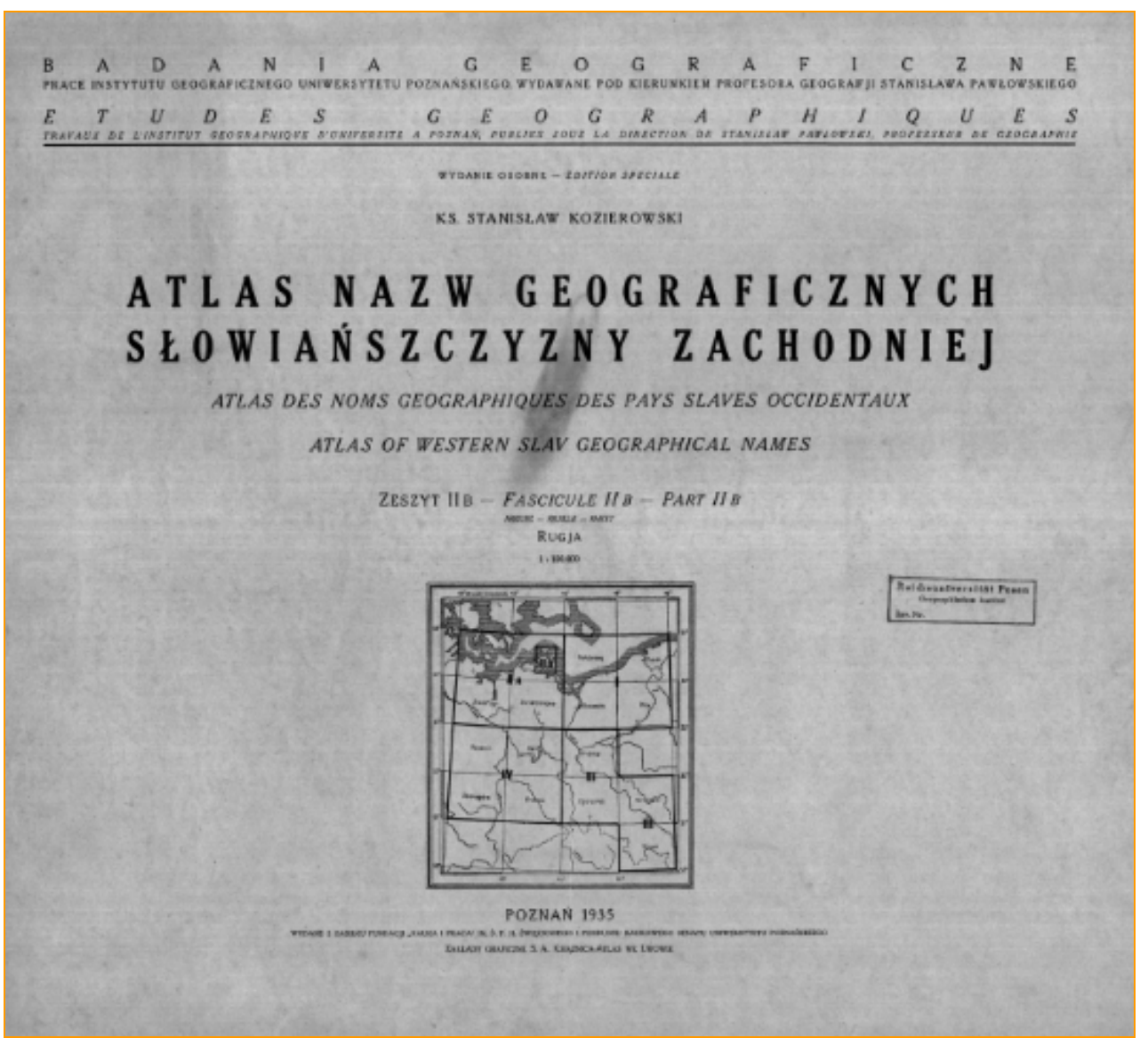

Fot. 4. Atlas nazw geograficznych Stowiańszczyzny Zachodniej (1935), opracowany pod kierunkiem S. PAWŁOWSKIEGO 
Działalność turystyczna, jak i krajoznawcza w formie zinstytucjonalizowanej w postaci PTK była w opinii S. Pawłowskiego istotnym źródłem wiedzy geograficznej.

Godnymi poparcia są przeto przede wszystkim programowe wydawnictwa Towarzystwa Krajoznawczego, jak „Ziemia” i wiele drobnych publikacji o charakterze popularnym, jak również objęty niedawno przez Towarzystwo „Pamiętnik Fizjograficzny". Czasopismo to było do niedawna jedynym pismem naukowym, w którym ukazywały się prace, odnoszące się do fizjografii Królestwa Polskiego i dziś jeszcze, jednocząc w sobie te działy nauk przyrodniczych, które $\mathrm{z}$ geografią pozostają $\mathrm{w}$ najbliższej styczności, zawiera najwięcej prac oryginalnych i materiału, niepozbawionego znaczenia dla geografów. Dodać jeszcze trzeba, że ma osobny dział publikacyjny: Geografia (PAWŁOWSKI 1919).

Wydarzenia II wojny światowej odbiły swoje piętno w historii rozwoju poznańskiego ośrodka geograficznego. Prof. S. Pawłowski został rozstrzelany w 1940 r. Jego następcy podjęli kontynuację wyznaczonych przez Profesora kierunków badań i działań, także w zakresie współpracy z Polskim Towarzystwem Turystyczno-Krajoznawczym.

\section{Nurt fizycznogeograficzny}

W okresie powojennym istotny wpływ na rozwój poznańskiego ośrodka geograficznego wywarły prace prof. Tadeusza Bartkowskiego (fot. 5). W jego opracowaniach (podobnie jak w pracach S. Pawłowskiego) podkreślany był stosowany charakter badań geograficznych. Problemy związane z turystyką i rekreacją T. Bartkowski łączył z możliwościami praktycznego wykorzystania opracowań fizycznogeograficznych. Początkowo skupiał się głównie na opracowaniu metodyki oceny przydatności środowiska przyrodniczego dla różnych form zagospodarowania (BARTKOWSKI 1974), dążąc do sformułowania jej spójnej teorii i metodyki (BARTKOWSKI 1977).

W kolejnych pracach T. Bartkowski coraz więcej uwagi poświęcał zagadnieniom związanym z geograficznymi uwarunkowaniami rozwoju turystyki i wypoczynku. Opracował wydany w dwóch częściach skrypt dla studentów turystyki oraz geografii - Wypisy do geografii turystycznej (BARTKOWSKI 1977, 
1980). Obie części (fot. 6, fot. 7) ukazały się pod auspicjami Akademii Wychowania Fizycznego w Poznaniu, ze względu na zaangażowanie Profesora w uruchomienie w 1974 r. na tej uczelni pierwszego w Polsce Wydziału Turystyki i Rekreacji.

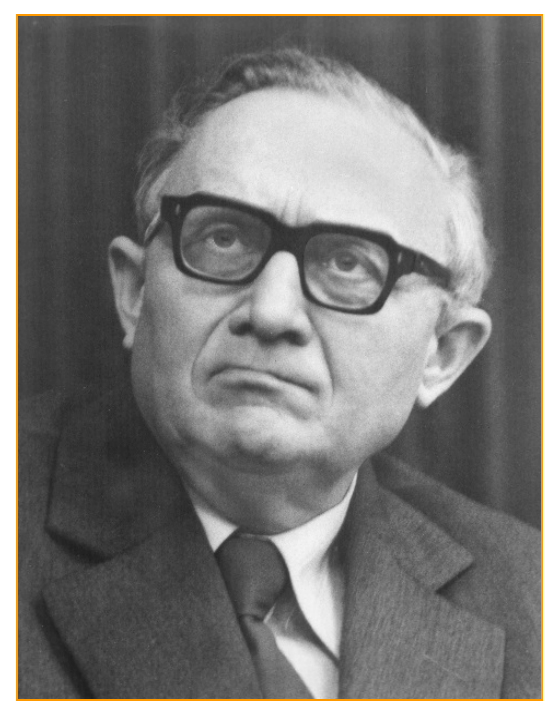

Fot. 5. Profesor Tadeusz Bartkowski (1920-1992)

Źródło: Archiwum WNGiG UAM w Poznaniu

Wypisy do geografii turystycznej, cz. I (BARTKOWSKI 1977b) stanowiły uporządkowany tematycznie zbiór artykułów wielu autorów. Została w nich przedstawiona dyskusja pojęć z zakresu geografii turystycznej. Omówiono definicję oraz miejsce geografii turystycznej wśród innych nauk geograficznych, ponadto pojęcie „,́rodowisko” i jego znaczenie dla rekreacji. Zdefiniowano także pojęcie „atrakcyjność turystyczna”, przedstawiono metody jej oceny zarówno $\mathrm{w}$ ujęciu teoretycznym, jak i na wybranych przykładach z uwzględnieniem zjawiska sezonowości. Przedstawione zostały także metody oceny pojemności i chłonności rekreacyjnej. Oddzielną grupę tematyczną stanowiły teksty dotyczące miast, ich funkcji turystycznych jako przedmiotu badań geografii turystycznej. Podręcznik zawiera także wytyczne dotyczące zagospodarowania turystycznego, prezentuje zasady wprowadzania infrastruktury turystycznej w zależności od typu krajobrazu i walorów turystycznych oraz natężenia ruchu turystycznego (rejony punktowe, pasmo- 
we, terytorialne), obejmuje zagadnienia ochrony przyrody i krajobrazu multisensorycznego. Druga część Wypisów do geografii turystycznej (BARTKOWSKI 1980):

będzie częścią szczegółową i regionalną i będzie dotyczyć przede wszystkim informacji geograficznej o atrakcyjności dla rekreacji terytoriów Polski i świata.

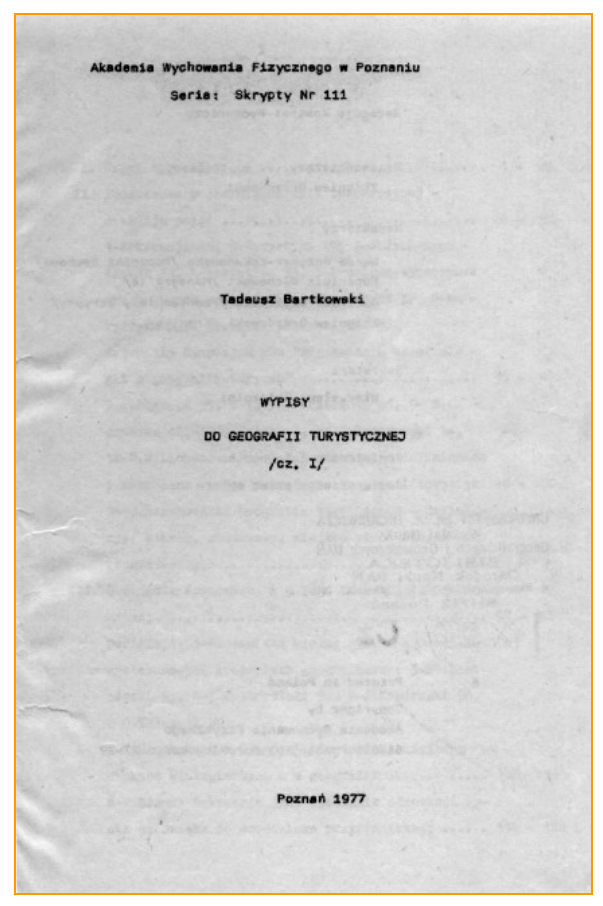

Fot. 6. Strona tytułowa dzieła T. BARTKOWSKIEGO,Wypisy do geografii turystycznej, cz. I (Poznań 1977b)

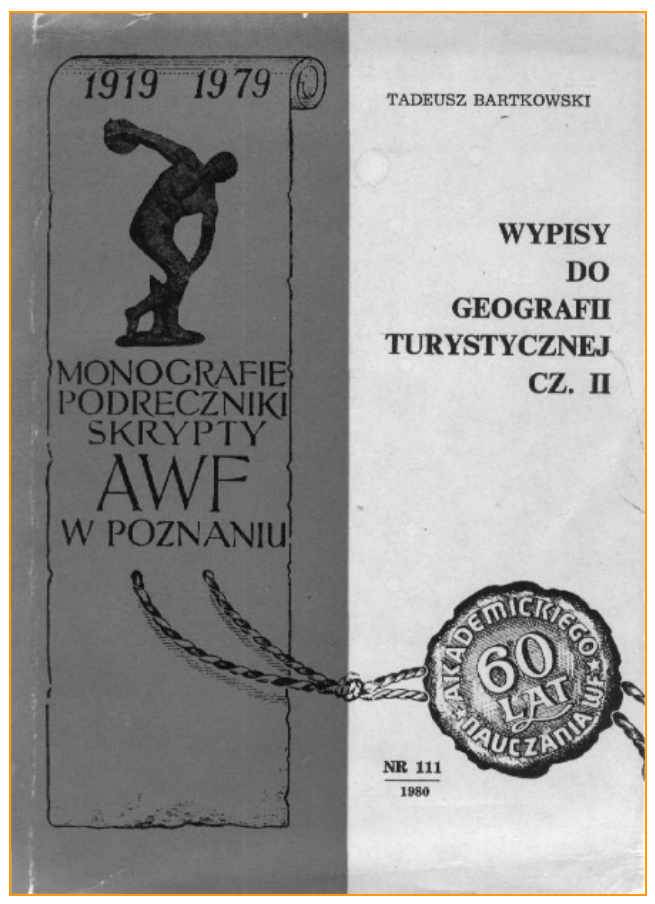

Fot. 7. Strona tytułowa dzieła T. BARTKOWSKIEGO, Wypisy do geografii turystycznej, cz. II (Poznań 1980)

W podręczniku tym znalazły się teoretyczne podstawy wykorzystania informacji geograficznej na użytek geografii turystycznej (w tym definicja krajoznawstwa, analiza informacji „labilnej” i „stabilnej” w przewodnikach turystycznych, jak również koncepcja struktury przewodnika krajoznawczego). Kolejne rozdziały poświęcono atrakcyjności turystycznej Polski oraz wybranych krajów, a ponadto globalnym aspektom rozwoju rekreacji.

$\mathrm{W}$ latach 80 . XX w. w pracach T. Bartkowskiego stało się widoczne przekonanie o konieczności ujmowania otaczającej człowieka przyrody w sposób 
interdyscyplinarny. Zostały one odzwierciedlone w podręczniku pt. Kształtowanie i ochrona środowiska człowieka (BARTKOWSKI 1991), zawierającym syntezę poglądów Profesora na temat definicji rekreacji, kształtowania infrastruktury obsługi rekreacji w mieście i strefie podmiejskiej oraz relacji: turystyka a środowisko i problem ochrony krajobrazu.

Geograficzne uwarunkowania rozwoju turystyki stanowiły przedmiot zainteresowań naukowych także prof. Andrzeja Marsza (fot. 8), związanego w latach 1963-1975 z Instytutem Geografii UAM.

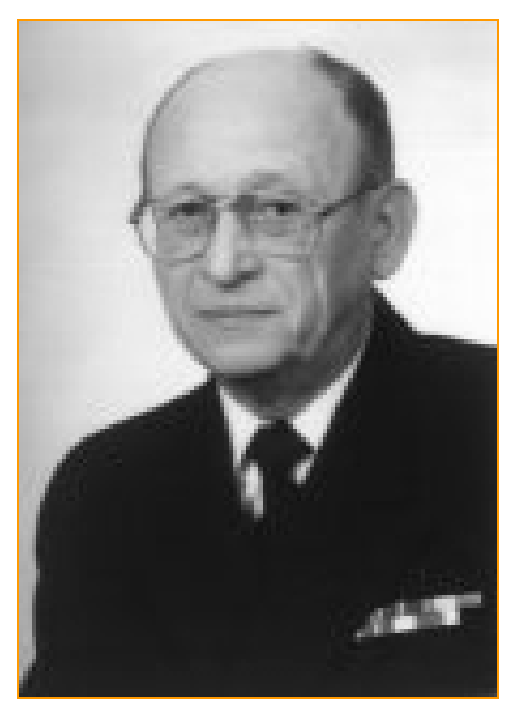

Fot. 8. Profesor Andrzej Marsz

Źródło: http:/ / ocean.am.gdynia

Prace $\mathrm{z}$ lat $60 . \mathrm{XX}$ w. ukierunkowane były na rozwój metodyki oceny środowiska przyrodniczego dla potrzeb turystyki i wypoczynku (MARSZ 1965a, 1965b, 1968, 1970). Prof. A. Marsz podjął próbę udoskonalenia technik obliczania chłonności i pojemności rekreacyjnej. W opracowaniu pt. Metoda obliczania pojemności rekreacyjnej ośrodków woypoczynkowych na niżu (MARSZ 1972, fot. 9) przedstawił procesy degradacji środowiska zachodzące w efekcie rekreacyjnego użytkowania terenu. Dążył do identyfikacji elementów środowiska geograficznego, które wpływają na określenie naturalnej pojemności rekreacyjnej obszaru i ustalenia modelu ich zależności. W analizach uwzględnił związek między zagospodarowaniem turystycznym a pojemnością re- 
kreacyjną terenu. Oryginalny pod względem zaproponowanej metodyki badań był przykład obliczania pojemności rekreacyjnej planowanego ośrodka turystycznego z uwzględnieniem takich cech jego otoczenia, jak: odporność runa na deptanie, nachylenie terenu oraz właściwości mechaniczne gruntu.

W miarę rozwoju badań geograficznych obok geografii fizycznej kształtowała się problematyka badań społecznych i ekonomicznych. Pomimo że określenie „geografia społeczna” zostało do literatury polskiej wprowadzone

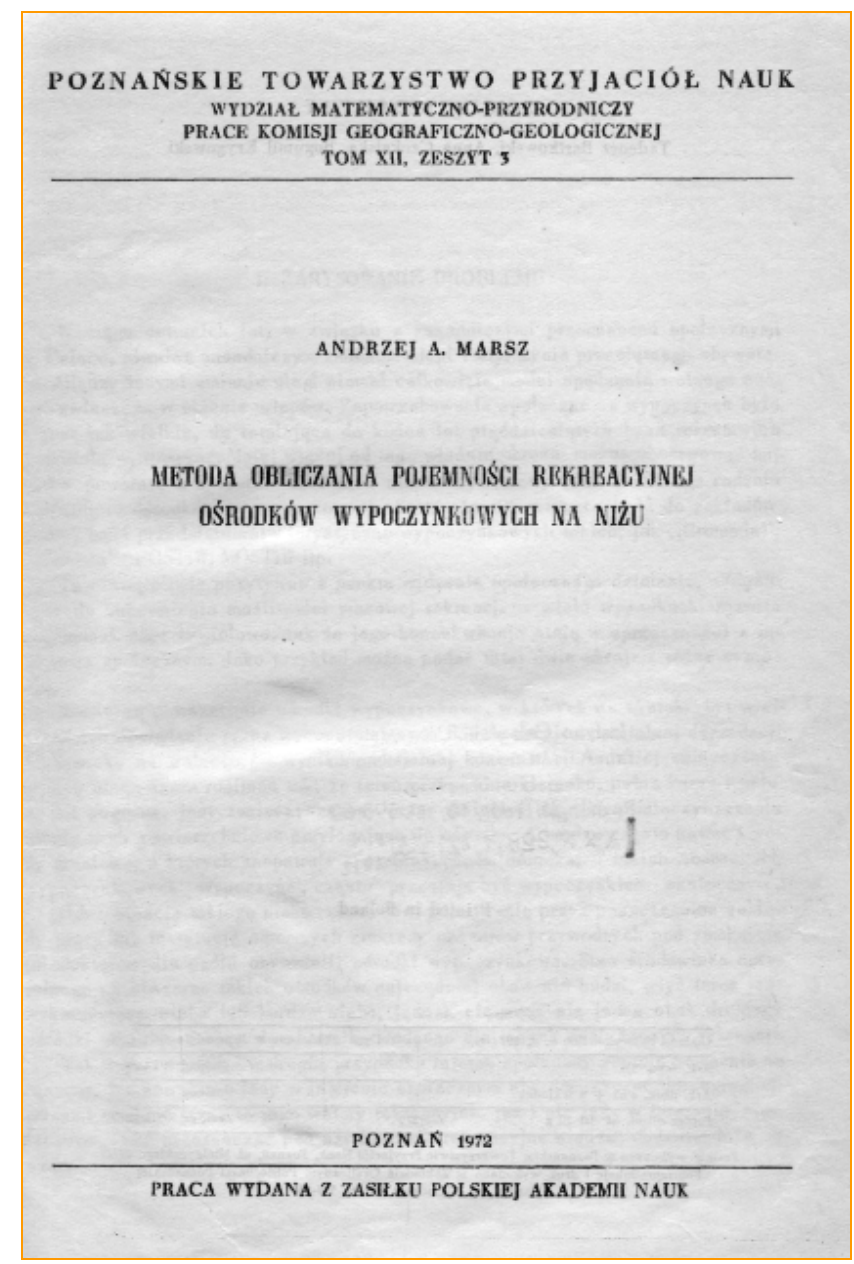

Rys. 9. Strona tytułowa dzieła Andrzeja Marsza, Metoda obliczania pojemności rekreacyjnej ośrodków wypoczynkowych na niżu (Poznań 1972) 
w 1929 r. (prawdopodobnie przez poznańskiego geografa Stanisława Nowakowskiego, za: LISOWSKI 2008), to usankcjonowanie odrębności tematyki społecznej w geografii polskiej nastąpiło dopiero w 1983 r. na konferencji w Rydzynie (LISOWSKI 2008). Zmiana ta znalazła odzwierciedlenie także $\mathrm{w}$ problematyce badań, podejmowanej $\mathrm{w}$ poznańskim ośrodku geograficznym.

\section{Nurt społeczno-ekonomiczny}

W nurcie badań społeczno-ekonomicznych geografia turyzmu była od wczesnych lat $80 . X X$ w. przedmiotem zainteresowania prof. Eugeniusza Bidermana (fot. 10). Do poruszanych przez niego zagadnień należały m.in. teoretyczne aspekty regionu turystycznego i metody jego delimitacji (BIDERMAN 1982a), uwarunkowania przestrzenne zagospodarowania turystycznego, jego struktura i wykorzystanie (BIDERMAN 1980a, 1980b, 1980c, 1981, 1982b, 1984), a także występowanie walorów turystycznych i krajoznawczych (m.in. BIDERMAN 1986). Obszar badań stanowiła głównie Wielkopolska (fot. 11).

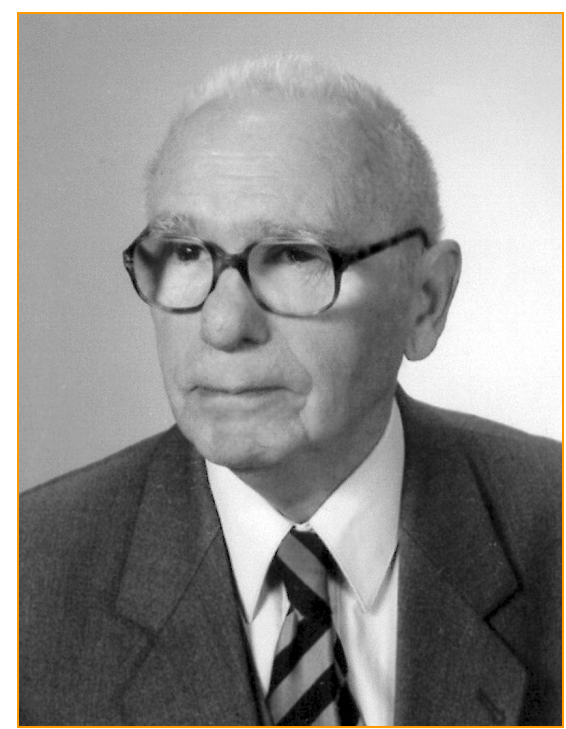

Rys. 10. Profesor Eugeniusz Biderman (1920-2012)

Źródło: Archiwum WNGiG UAM w Poznaniu 


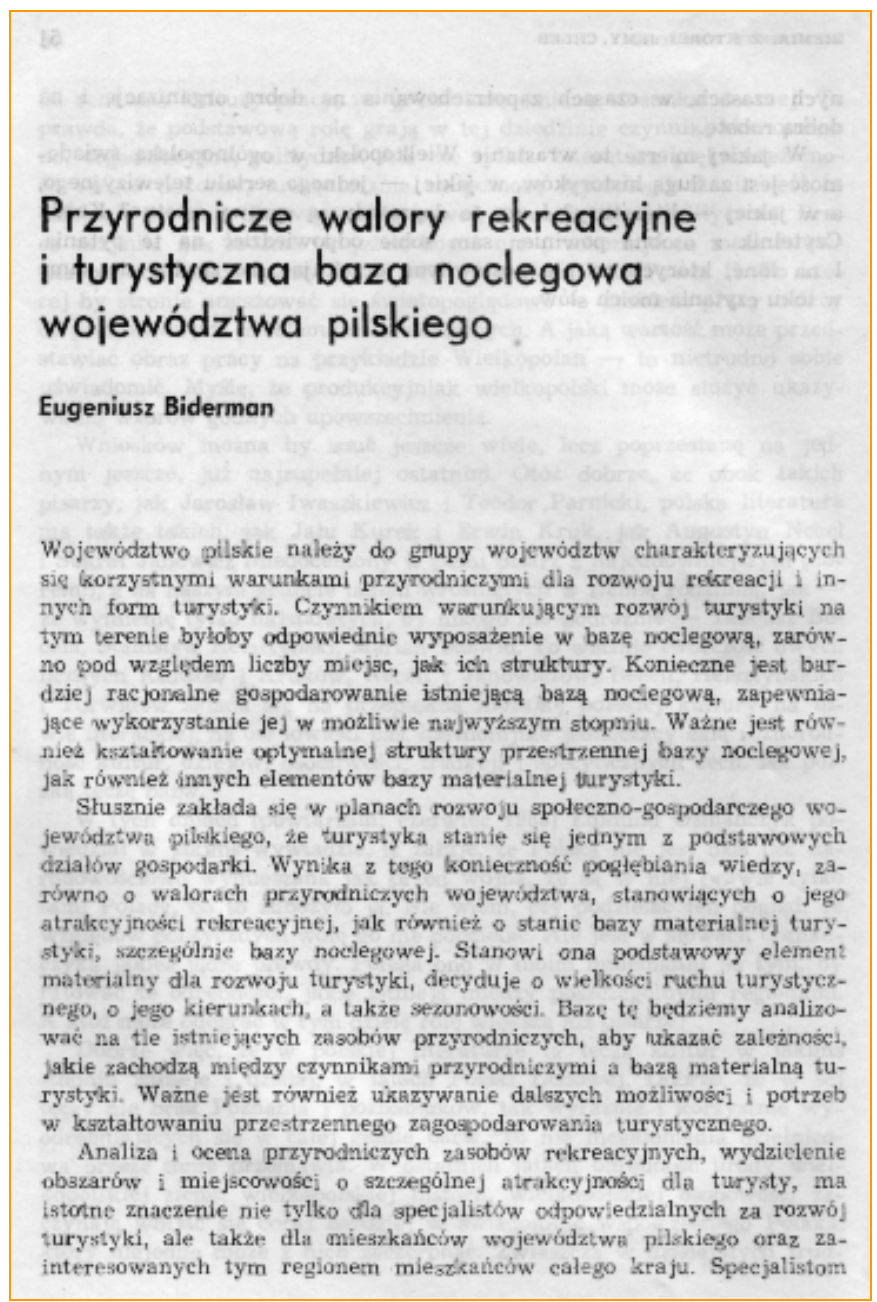

Rys. 11. Strona tytułowa artykułu Eugeniusza

Bidermana, ,'Kronika Wielkopolski” 1(33),

(Warszawa-Poznań 1984)

W opracowaniu przeglądowym pt. Basic Research Directions of Tourist Geography of the Poznań University (BIDERMAN 1991) Profesor omówił główne kierunki badań z zakresu geografii turyzmu podejmowane na UAM. Problemy badań zainicjowane przez E. Bidermana są współcześnie rozwijane zarówno w nurcie geografii społeczno-ekonomicznej, gospodarki przestrzennej, jak i geografii turyzmu. 


\section{Nurt badań kompleksowych}

Kontynuację badań z zakresu metodyki ocen środowiska przyrodniczego na potrzeby rozwoju różnych funkcji gospodarczych (w tym turystyki i wypoczynku) stanowiły prace prof. Danieli Sołowiej (fot. 12), prowadzone w ramach geografii fizycznej kompleksowej (SOŁOWIEJ 1977, 1979, SOŁOWIEJ, PASEK 1979). Wiązały się one także z geografią turyzmu, geografią rekreacji, jak również problemami geoekologii turystyki i wypoczynku. Prof. D. Sołowiej przyczyniła się do rozwoju teorii terytorialnych systemów rekreacyjnych oraz identyfikacji konfliktów: człowiek-środowisko przyrodnicze.

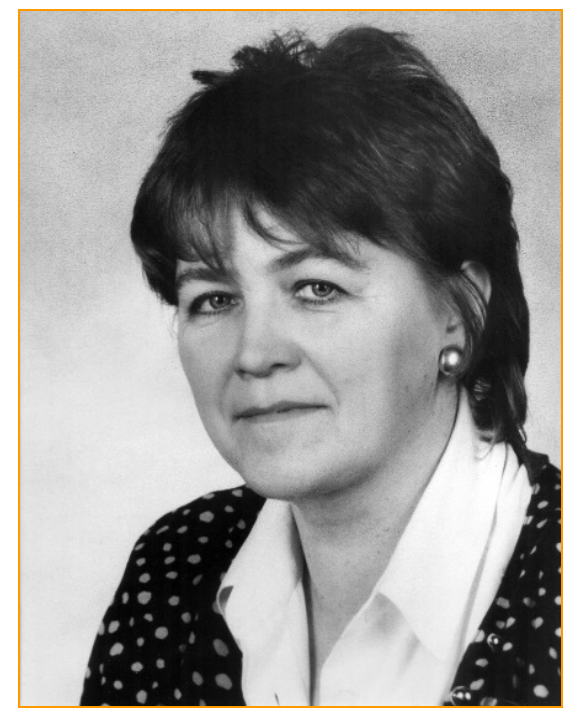

Fot. 12. Profesor Daniela Sołowiej

(1948-2000)

Źródło: Archiwum WNGiG UAM w Poznaniu

W podręczniku dla studentów kierunku „geografia” pt. Podstawoy metodyki oceny środowiska przyrodniczego człowieka (SOŁOWIEJ 1986, 1992a) omówiła m.in. metody oceny przydatności rekreacyjnej środowiska naturalnego, z uwzględnieniem różnych skal opracowania. W skrypcie tym oraz w innych pracach $z$ lat 80. XX w. (SOŁOWIEJ, PASEK 1980, SOŁOWIEJ 1981) analizie poddano także cechy przyrodnicze, które mogą stanowić bariery dla rozwoju funkcji rekreacyjnej. Za cenny wkład tych publikacji w rozwój metod 
oceny naturalnego potencjału rekreacyjnego należy uznać podkreślanie konieczności uwzględniania w tym procesie danych o jakości środowiska przyrodniczego. Natomiast w metodyce obliczania chłonności rekreacyjnej zwrócono uwagę na różny stopień „agresywności” form wypoczynku, który obok odporności środowiska na degradację - determinuje wartość tego wskaźnika.

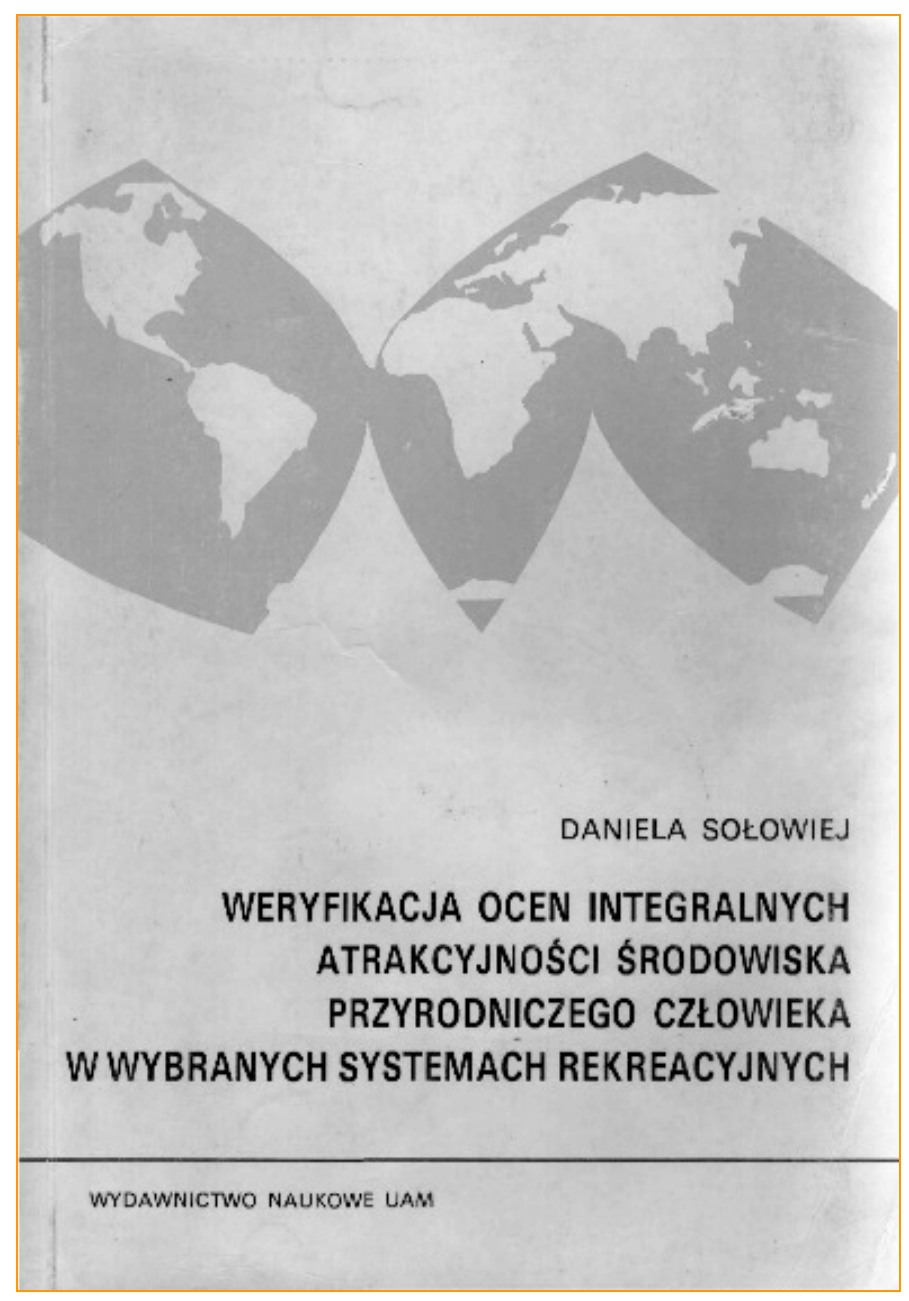

Rys. 13. Strona tytułowa dzieła Danieli Sołowiej: Weryfikacja ocen integralnych atrakcyjności środowiska przyrodniczego człowieka w wybranych systemach rekreacyjnych

(Poznań 1992) 
Jednym z głównych celów pracy habilitacyjnej (fot. 13) pt. Weryfikacja ocen integralnych atrakcyjności środowiska przyrodniczego człowieka w woybranych systemach rekreacyjnych (SOŁOWIEJ 1992b) było ukazanie konieczności „humanizacji" nastawienia badawczego, tj. uwzględniania różnorodności potrzeb człowieka i znaczenia, jakie niesie ze sobą ich znajomość dla planowania przestrzennego. $Z$ uwagi na fakt, iż „ocena środowiska przyrodniczego dla rekreacji jest bardzo złożona i wieloaspektowa” (op.cit.) wprowadzono pojęcie oceny integralnej. Głównym problemem badawczym rozprawy była:

konfrontacja, a przez to także weryfikacja oceny integralnej - między innymi z: nowymi danymi dotyczącymi np. stopnia degradacji środowiska przyrodniczego, percepcją miejsc dla rekreacji przez osoby planujące wypoczynek, jak i osoby wypoczywające, z potrzebami rekreacyjnymi itd. (SOŁOWIEJ 1992b).

Praca ujawnia krytyczne podejście do metodyki oceny atrakcyjności środowiska przyrodniczego dla rekreacji, zawiera także uzasadnienie większej rangi metody ograniczeń (barier), traktowanej jako metoda konkurencyjna w stosunku do metody oceny atrakcyjności, oraz wykazuje zasadność kartowania sozologicznego jako podstawy weryfikacji tej oceny. Do metodycznego novum należał fakt, że:

zaproponowany sposób rozwiązywania problemu jest efektem analizy poglądów na problemy rekreacji zarówno badacza (teoretyka), jak i centralnego obiektu każdego systemu rekreacyjnego, którym może być stały mieszkaniec systemu planujący wypoczynek, jak i rekreant właściwy (SOŁOWIEJ 1992).

Uwzględnienie humanistycznych aspektów badań widoczne jest w wielu opracowaniach D. Sołowiej z lat 90. XX w. To podejście ujawnia się w pracach prezentujących m.in. typologię zajęć rekreacyjnych w cyklu urlopowym (SOŁOWIEJ 1992b), przyczyny dyskomfortu wypoczynku (SOŁOWIEJ 1993), wykorzystanie przestrzeni rekreacyjnej (SOŁOWIEJ, BRZÓSKA, KRAWCZYK 1995) czy tworzenie modeli zagospodarowania turystycznego z zastosowaniem zasady strefowania (SOŁOWIEJ 1996), jak również metody symulacji zagospodarowania rekreacyjnego (SOŁOWIEJ, BRZÓSKA, KRAWCZYK 1996).

D. Sołowiej brała udział w projekcie dotyczącym planów rozwoju turystyki w byłym województwie gorzowskim (1994-1997), kierowała także grupą syntezy w interdyscyplinarnym polsko-niemieckim projekcie WWF Zielona Wstega Odra-Nysa. Koncepcja aktyzunej ochrony przyrody (SOŁOWIEJ, BŁOSZYK, red. 1999). W latach 1993-1997 realizowała kolejny projekt badawczy 
dotyczący wykorzystania czasu wolnego oraz przyczyn dyskomfortu wypoczynku Wielkopolan. Opracowała modele wykorzystania czasu wolnego, przeprowadziła delimitację obszarów atrakcyjnych dla rekreacji - a w konsekwencji wydzieliła systemy i kompleksy turystyczno-rekreacyjne w Wielkopolsce. Podsumowaniem tych badań miała być przygotowywana do dru$\mathrm{ku}$ publikacja pt. Systemy rekreacyjne Wielkopolski na tle wykorzystania gospodarczego regionu. Niestety, prace nad tym projektem przerwała niespodziewana śmierć. Część wyników badań ukazała się jedynie w artykule (SOŁOWIEJ, BRÓDKA 1998).

D. Sołowiej od 1999 r. do przedwczesnej śmierci (w 2000 r.) kierowała Zakładem Przyrodniczych Podstaw Planowania Przestrzennego i Turystyki w Instytucie Geografii Fizycznej i Kształtowania Środowiska Przyrodniczego UAM. Pod jej kierunkiem realizowano kilka przewodów doktorskich, poruszających problemy turystyki. Zainicjowane przez nią kierunki badań stanowią niezmiennie źródło inspiracji dla jej uczniów.

\section{Podsumowanie}

Nakreślona historia rozwoju badań związanych z krajoznawstwem, turystyką i rekreacją podejmowanych $\mathrm{w}$ poznańskim ośrodku geograficznym wskazuje na ich ewolucję, związaną zarówno z rozwojem nauk geograficznych, jak i przedmiotu badań (skali i zróżnicowania turystyki, form rekreacji, krajoznawstwa).

1. W pierwotnym "krajoznawczym” nurcie badań traktowano krajoznawstwo i turystykę jako istotne źródła wiedzy geograficznej, ale także wskazywano na znaczenie badań geograficznych jako źródła użytecznej wiedzy w organizacji turystyki i krajoznawstwa, podkreślając stosowany charakter informacji geograficznych.

2. Kontynuacja rozwoju badań stosowanych była widoczna w pracach fizycznogeograficznych ukierunkowanych m.in. na doskonalenie metodyki oceny środowiska przyrodniczego na potrzeby rozwoju turystyki i wypoczynku (do popularnych należała metoda bonitacji punktowej), uwzględniano także wartości progowe obciążenia terenu ruchem turystycznym (wskaźniki chłonności rekreacyjnej/turystycznej), jak również bariery rozwoju turystyki i rekreacji związane z cechami środowiska przyrodniczego. 
3. Wyłonienie się geografii społeczno-ekonomicznej w strukturze nauk geograficznych spowodowało większe zainteresowanie wśród geografów problemami ruchu turystycznego oraz zagospodarowania turystycznego w ujęciu przestrzennym.

4. Wyniki badań empirycznych, stosowanych dały podstawę do budowy modeli. Adaptowano w tym celu teorię systemu, której założenia wykorzystano $w$ tworzeniu koncepcji ",systemowego ujęcia środowiska przyrodniczego", "terytorialnych systemów rekreacyjnych" "multisensorycznej percepcji krajobrazu” czy „regionu turystyczno-usługowego".

5. Rozwój badań stosowanych, jak i podstawowych (ujęć teoretycznych) prowadził do prób syntezy wyników badań szczegółowych, a w konsekwencji do podejmowania prac o charakterze kompleksowym (uwzgledniających zróżnicowaną gamę zmiennych tworzących systemy turystyki lub/i rekreacji).

6. Kolejny etap obserwowany na drodze ewolucji badań geograficznych związany jest z rozwojem ujęć interdyscyplinarnych, systemowych, pozwalających na rozpoznanie nie tylko komponentów systemu turystyki czy rekreacji, ale także przy uwzględnieniu właściwości emergentnych tych systemów - zrozumienie sieci zależności występujących między tymi komponentami. Skutkiem tego typu założeń jest rozwój zarówno funkcji informacyjnej (identyfikacja ,jak jest?”), jak i eksplanacyjnej (wyjaśnianie „dlaczego tak jest?”) badań geograficznych.

7. Współcześnie obserwowana jest kontynuacja badań z zakresu turystyki i rekreacji prowadzonych zarówno przez przedstawicieli geografii fizycznej, społeczno-ekonomicznej, jak i w wyodrębnionym w 2000 r. na Wydziale Nauk Geograficznych i Geologicznych Centrum Turystyki i Rekreacji. Zainteresowanie tego typu problematyką badań ma miejsce także w Instytucie Geologii (dotyczy głównie geoturystyki, turystyki jaskiniowej, wspinaczki skałkowej, czyli form turystyki bazujących na walorach litosfery).

8. Odniesienie przedstawionej w zarysie historii rozwoju zainteresowań badawczych geografów problematyką turystyczną do ewolucji badań $\mathrm{z}$ zakresu turystyki przedstawionych $\mathrm{w}$ szerszym, międzynarodowym kontekście (JENNINGS 2010) wskazuje na wiele analogii, związanych z przejściem od badań szczegółowych - multidyscyplinarnych, do badań o charakterze interdyscyplinarnym - stanowiących 
próbę systemowego ujęcia zjawiska turystyki. Taka zamiana paradygmatu pozwala na pogłębienie badań wyjaśniających, których wyniki moga przyczynić się $\mathrm{w}$ istotny sposób do rozwoju teorii charakterystycznych dla samej turystyki.

\section{LITERATURA}

Atlas nazw geograficznych Stowiańszczyzny Zachodniej, 1935, „Badania Geograficzne”, Prace Instytutu Geograficznego Uniwersytetu Poznańskiego, pod kier. prof. geogr. S. Pawłowskiego, Poznań.

BARTKOWSKI T., 1974, Zastosowania geografii fizycznej, PWN, Warszawa-Poznań.

BARTKOWSKI T., 1977a, Metody badań geografii fizycznej, PWN, Warszawa-Poznań.

BARTKOWSKI T., 1977b, Wypisy do geografii turystycznej, cz. I, „Monografie. Podręczniki. Skrypty, AWF w Poznaniu", ser. 111.

BARTKOWSKI T., 1980, Wypisy do geografii turystycznej, cz. II, „Monografie. Podręczniki. Skrypty, AWF w Poznaniu", ser. 111.

BARTKOWSKI T., 1991, Ksztattowanie i ochrona środowiska człowieka, wyd. 5., zmienione, PWN, Warszawa.

BARTKOWSKI E., 1980a, Struktura zagospodarowania turystycznego województwa leszczyńskiego, „Rocznik Leszczyński" 4, s. 9-36.

BIDERMAN E., 1980b, Struktura przestrzenna i funkcjonalna podmiejskich obszarów rekreacyjnych, [w:] Zasady ksztattowania podmiejskich obszarów rekreacyjnych, ser. „Monografie” 146, Wyd. AWF, Poznań, s. 29-49.

BIDERMAN E., 1980c, Czynniki przestrzennego zagospodarowania turystycznego województwa konińskiego, „Rocznik Koniński” 8, s. 133-137.

BIDERMAN E., 1981, Struktura i wykorzystanie bazy noclegowej w obiektach turystycznych $i$ wczasowo-wypoczynkowych województwa poznańskiego, „Kronika Wielkopolski” 1, s. 76-94.

BIDERMAN E., 1982a, Teoretyczne problemy regionu ekonomicznego a pojęcie i zasady wydzielania regionu turystyczno-ustugowego, [w:] Problemy regionalizacji turystycznej, ser. „Skrypty” 201, AWF Poznań.

BIDERMAN E., 1982b, Wykorzystanie bazy noclegowej w obiektach turystycznych i wczasowo-wypoczynkowych województwa konińskiego, „Rocznik Koniński” 10, s. 229-244.

BIDERMAN E., 1984, Przyrodnicze walory rekreacyjne i turystyczna baza noclegowa województwa pilskiego, „Kronika Wielkopolski” 1, s. 52-76.

BIDERMAn E., 1986, Walory krajoznawcze i turystyczne, [w:] Polska nad Odra i Bałtykiem, S. Sierpowski (red.), Wyd. Instytutu Zachodniego, Poznań, s. 108-112.

BIDERMAN E., 1991, Basic Research Directions of Tourist Geography of the Poznań University, „Prace Geograficzne UJ" 86, s. 125-127.

JENNINGS G., 2010, Tourism research, Griffith University, Wiley, Australia.

LISOWSKI A., 2008, Geografia spoteczna, [w:] Historia geografii polskiej, A. Jackowski, S. Liszewski, A. Richling (red.), Wyd. Naukowe PWN, Warszawa, s. 195-205.

MARSZ A., 1965 a, Koncepcja mapy ogólnej oceny terenu dla potrzeb turystyki i wypoczynku, Sprawozdania PTPN za III i IV kwartał 1965 r., 2 (ogólny zbioru - 74), Poznań.

MARSZ A., 1965b, Ocena środowiska geograficznego rynny jezior Kórnicko-Zaniemyskich dla potrzeb turystyki i wypoczynku, Sprawozdania PZPN za III i IV kwartał 1965 r., Poznań.

MARSZ A., 1968, Analiza prac konkursowych pod względem treści fizjograficznej, metod oceny środowiska geograficznego dla potrzeb planowania w zakresie rekreacji i obliczania chłonności rekreacyjnej obszaru, Konkurs Towarzystwa Urbanistów Polskich, 8/68 (mps), Poznań. 
MARSZ A., 1970, Ocena środowiska geograficznego rynny Jezior Kórnicko-Zaniemyskich dla potrzeb turystyki $i$ wypoczynku jako przykład wykorzystania mapy uroczysk do oceny w dużej podziałce, Zeszyty Naukowe UAM, „Geografia” 9.

MARSZ A., 1972, Metoda obliczania pojemności rekreacyjnej ośrodków wypoczynkowych na niżu, „Prace Komisji Geograficzno-Geologicznej” XII 3, PZPN, Poznań, ss. 72.

PAWŁOWSKI S., 1919, O potrzebach geografii polskiej, „Nauka Polska” 2, s. 64-69.

PAWŁOWSKI S., 1939, Rola geografii w życiu narodów, „Czasopismo Geograficzne” XVII, 1, s. 1-2.

PAWŁOWSKI Z. S., 2006, Prof. dr fil. Stanistaw Pawtowski. 1882-1940, Poznań.

SOŁOWIEJ D., 1977, Zdjęcie uroczysk jako punkt wyjścia do oceny kompleksowej terenu dla potrzeb rekreacji (na przyktadzie okolic jeziora Komorze - Pojezierze Drawskie), [w]: Wypisy do geografii turystycznej, cz. I, Poznań, s. 238-243.

SOŁOWIEJ D., 1979, Stan degradacji środowiska przyrodniczego w wybranych krajobrazach Jeziora Jaroszewskiego i Jeziora Wisetka a konieczność weryfikowania kryteriów oceny dla rekreacji w skali planowania miejscowego, [w:] Ocena atrakcyjności środowiska geograficznego dla potrzeb turystyki i rekreacji na różnych poziomach i etapach planowania. Materiaty konferencji naukowej - Poznań, dnia 19 i 20 listopada 1977 r., AWF w Poznaniu, ser. „Monografie” 116, s. 35-56.

SOŁOWIEJ D., 1981, Ocena stopnia atrakcyjności i przydatności strefy brzegowej wybranych jezior woj. leszczyńskiego dla rekreacji. Materiaty konferencyjne opublikowane w zbiorze pt. „Wybrane zagadnienia ochrony i ksztattowania środowiska w regionie Wielkopolskim", PTPNoZ, Oddział Wielkopolski w Poznaniu, s. 16-26.

SOŁOWIEJ D., 1986, Podstawy metodyki oceny środowiska przyrodniczego cztowieka, Wyd. Naukowe UAM, Poznań.

SOŁOWIEJ D., 1992a, Podstawy metodyki oceny środowiska przyrodniczego człowieka, wyd. II, poszerzone, Wyd. Naukowe UAM, Poznań, ss. 165.

SOŁOWIEJ D., 1992b, Weryfikacja ocen integralnych atrakcyjności środowiska przyrodniczego człowieka w wybranych systemach rekreacyjnych, Wyd. Naukowe UAM, Poznań, ss. 165.

SOŁOWIEJ D., 1993, Przyczyny braku komfortu mieszkania w systemie rekreacyjnym miasta Poznania, [w:] Ekologia krajobrazu w wybranych terytorialnych systemach rekreacyjnych, Wyd. Krajowego Instytutu Badań Samorządowych, Poznań, s. 101-107.

SOŁOWIEJ D., 1996, Idea strefowania funkcji na obszarach chronionych jako podstawa rozwiazywania konfliktów cztowiek - środowisko przyrodnicze. Badania fizjograficzne nad Polską Zachodnia, ser. A „Geografia Fizyczna" 47, Poznań, s. 101-114.

SOŁOWIEJ D., BŁosZYK J. (red.), 1999, Podstawy ekorozwoju "Zielonej Wstegi Odra-Nysa”. Polska strona projektu, Wyd. Kontekst, Poznań, ss. 343.

SOŁOWIEJ D., BRZÓSKA J., KRAWCZYK P., 1995, Modele rozpraszania się rekreantów jako podstawa do obliczania naturalnej chtonności rekreacyjnej Stowińskiego Parku Narodowego. Studia z geografii fizycznej, Sprawozdanie Wydz. Matematyczno-Przyrodniczego 109, za lata 1991-1994, cz. 1, Wyd. PTPN, Poznań, s. 139-144.

SOŁOWIEJ D., BRZÓSKA J., KRAWCZYK P., 1996, Metoda symulacji sposobów zagospodarowania rekreacyjnego Stowińskiego Parku Narodowego jako punkt wyjścia do obliczeń naturalnej chłonności rekreacyjnej, Badania Fizjograficzne nad Polską Zachodnią, ser. „Geografia Fizyczna” 47, Poznań, s. 17-28.

SOŁOWIEJ D., BRÓDKA S., 1998, Podziat i walory przestrzeni turystyczno-rekreacyjnej Wielkopolski, [w:] Wielkopolska. Monografia regionu, Wyd. Koziołki Poznańskie, Poznań, s. 143-175.

SOŁOWIEJ D., PASEK H., 1979, Analiza struktury uroczysk strefy brzegowej Jeziora Jaroszewskiego w aspekcie ich wykorzystania rekreacyjnego, Badania Fizjograficzne nad Polską Zachodnią, ser. „Geografia Fizyczna" 32, Poznań, s. 63-83.

SOŁOWIEJ D., PASEK H., 1980, Stopień degradacji środowiska przyrodniczego jako konieczne kryterium oceny rzeczywistych możliwości wykorzystania środowiska przyrodniczego dla potrzeb wybranych form rekre- 
acji, [w:] Metodologia badań w turystyce, „Monografie. Skrypty. Podręczniki AWF w Poznaniu” 129, s. 153-160.

SzUKALSKI J., 1985, Geografowie i geografia w „Ziemi”. 1985, [w:] Ziemia, Wyd. PTTK „Kraj”, Warszawa, ss. 140.

\section{THE “PAST SIMPLE” OF RESEARCH ON TOURISM, SIGHTSEEING AND LEISURE AT THE ADAM MICKIEWICZ UNIVERSITY IN POZNAN}

Key words: sightseeing, tourism geography, leisure geography

\section{Summary}

The aim of the paper is to recount the contribution of geographers from Adam Mickiewicz University in Poznań into research on tourism, sightseeing and leisure in a historical perspective, i.e., from the foundation of the Institute of Geography in 1919 until 2000. Based on the analysis of scientific publications available in the Library of the Faculty of Geographical and Geological Science, a number of research trends have been identified (and their representatives have been named). These include: the sightseeing trend (Prof. S. Pawłowski), the physical and geographical trend (Prof. T. Bartkowski, Prof. A. Marsz), the socio-economic trend (Prof. E. Biderman), and the comprehensive research trend (Prof. D. Sołowiej). A historically-oriented analysis of the research problems points to their evolution, which was connected with both the development of geographical science and the development of the subject of the research (the scale and diversity of tourism, forms of recreation, sightseeing). Numerous analogies can be found between tourism research conducted at Adam Mickiewicz University and that carried out globally, e.g. the transition from specific (multidisciplinary) research to interdisciplinary one, aimed at presenting tourism and recreation in a systemic perspective. 